\title{
Identification of CIC-2 and CIC-K2 Chloride Channels in Cultured Rat Type IV Spiral Ligament Fibrocytes
}

\author{
Chunyan Qu ${ }^{1}$, Fenghe Liang ${ }^{1}$, Nancy M. Smythe ${ }^{2}$, and Bradley A. Schulte ${ }^{1,2}$ \\ ${ }^{1}$ Department of Pathology and Laboratory Medicine, Medical University of South Carolina, 165 Ashley Avenue, Suite 309, \\ P.O. Box 250908, Charleston, SC 29425, USA \\ ${ }^{2}$ Department of Otolaryngology-Head and Neck Surgery, Medical University of South Carolina, Charleston, SC 29425, USA
}

Received: 28 June 2006; Accepted: 26 December 2006; Online publication: 2 March 2007

\begin{abstract}
Voltage-gated chloride channels (ClCs) are important mediators of cellular ion homeostasis and volume regulation. In an earlier study, we used immunohistochemical, Western blot, and reverse transcriptase PCR (RT-PCR) approaches to identify ClC-K variants in types II, IV, and V fibrocytes of the rodent spiral ligament. We have now confirmed the expression of ClC-K2 in these cells by in situ hybridization. All three of these fibrocyte subtypes are thought to be involved in cochlear $\mathrm{K}^{+}$recycling; thus, it is important to understand the precise mechanisms regulating their membrane conductance and the role played by ClCs in this process. In this study, we report the characterization of a secondary cell line derived from explants from the region of the rat spiral ligament underlying and inferior to the spiral prominence. The cultured cells were immunopositive for vimentin, Na,K/ATPase, $\mathrm{Na}, \mathrm{K}, \mathrm{Cl}-$ cotransporter, carbonic anhydrase isozyme II, and creatine kinase isozyme BB, but not for cytokeratins or $\mathrm{Ca} / \mathrm{ATPase}$, an immunostaining profile indicative of the type IV subtype. Evaluation of the cultures by RT-PCR and Western blot analysis confirmed the presence of both ClC-2 and -K2. Whole-cell patch clamp recordings identified two biophysically distinct $\mathrm{Cl}^{-}$currents in the cultured
\end{abstract}

Correspondence to: Bradley A. Schulte $\bullet$ Department of Pathology and Laboratory Medicine • Medical University of South Carolina • 165 Ashley Avenue, Suite 309, P.O. Box 250908, Charleston, SC 29425, USA. Telephone: +1-843-7922711; fax: +1-843-7920368; email: schulteb@musc.edu cells. One, an inwardly rectifying $\mathrm{Cl}^{-}$current activated by hyperpolarization or decreasing extracellular $\mathrm{pH}$ corresponded with the properties of ClC-2. The other, a weak outwardly rectifying $\mathrm{Cl}^{-}$current regulated by extracellular $\mathrm{pH}, \mathrm{Cl}^{-}$, and $\mathrm{Ca}^{2+}$ resembled the channel characteristics of ClC-K2 when expressed in Xenopus oocytes. These findings suggest that at least two functionally different chloride channels are involved in regulating membrane anion conductance in cultured type IV spiral ligament fibrocytes.

Keywords: chloride channel, ClC-K1, ClC-K2, ClC-2, cochlea, spiral ligament, fibrocytes

Abbreviations: CFTR - cystic fibrosis transmembrane conductance regulator; $\mathrm{ClC}$-voltage-gated chloride channel; EDTA-ethylenediaminetetraacetic acid; HRP - horseradish peroxidase; $\mathrm{PB}$ - phosphate buffer; PBS-phosphate-buffered saline; PBST-phosphate-buffered saline Tween-20; PVDF - polyvinylidene fluoride; RT-PCR - reverse transcription-polymerase chain reaction; SDS - sodium dodecyl (lauryl) sulfate; UV - ultraviolet

\section{INTRODUCTION}

At present, three families of chloride channels have been identified (Estevez and Jentsch 2002). The cystic fibrosis transmembrane conductance regulator (CFTR) was found in the epithelium of many tissues such as lung, colon, and pancreas and in other cell 
types such as heart muscle and lymphocytes (Riordan et al. 1989; Kunzelmann 1999). The ligand-gated chloride channels are predominantly expressed in the central nervous system. The voltage-gated chloride channel $(\mathrm{ClC})$ family has nine members so far identified in mammals, termed $\mathrm{ClC}-1$ to $-7,-\mathrm{K} 1$, and $-\mathrm{K} 2$ (Jentsch et al. 1993; Jentsch et al. 2005). The highly homologous chloride channel $\mathrm{ClC}-\mathrm{K} 1$ and $-\mathrm{K} 2$ subtypes, along with their common $\beta$-subunit barttin, were found in the kidney and inner ear. In the inner ear, ClC-Ks are present in strial marginal and vestibular dark cells, Deiters cells, spiral ganglion neurons, types II, IV, and V, and supralimbal fibrocytes and osteoclasts in the otic capsule (Ando and Takeuchi 2000; Estevez et al. 2001; Sage and Marcus 2001; Spicer et al. 2003; Qu et al. 2006). ClC-K1 and $-\mathrm{K} 2$ channels appear to be coexpressed in some inner ear cell types and may compensate for each other functionally as suggested by the preservation of hearing in the presence of a mutation in one but not both of the ClC-K variants (Simon et al. 1997; Matsumura et al. 1998; Estevez et al. 2001; Qu et al. 2006).

Fibrocytes in the cochlear lateral wall were classified into five major subtypes based on their distribution, morphology, and expression of specific protein markers (Spicer and Schulte 1991, 1996, 1998). Although types II, IV, and V fibrocytes occupy different localizations, similarities in their immunostaining profile for ion transport proteins and ultrastructural features suggest that they share a common activity, namely, the uptake of $\mathrm{K}^{+}$from perilymph for its return to endolymph via the hypothesized lateral $\mathrm{K}^{+}$ recycling pathway. It is probable that ClC-Ks mediate the exit of $\mathrm{Cl}^{-}$imported by $\mathrm{Na}, \mathrm{K} / \mathrm{ATPase}$ and $\mathrm{Na}, \mathrm{K}, \mathrm{Cl}-\mathrm{cotransporter}$ activities and maintain normal cellular electrical and ionic homeostasis in these fibrocytes (Crouch et al. 1997; Boettger et al. 2002; Qu et al. 2006).

Secondary cultures of type I spiral ligament fibrocytes have been successfully established (Gratton et al. 1996; Suko et al. 2000; Liang et al. 2003; Shen et al. 2004). Although these cells retain many of their in vivo characteristics and provide a good source for physiological studies, reports of the successful culture of other spiral ligament fibrocyte subtypes are lacking. In this study, we report the establishment of a type IV fibrocyte cell culture. The cultured cells were characterized immunocytochemically with protein markers specific to various spiral ligament fibrocyte subtypes. The expression of $\mathrm{ClC}-2$ and $-\mathrm{K} 2$ in the cultured fibrocytes was confirmed at the mRNA and protein levels. Whole-cell patch clamp studies revealed two discrete $\mathrm{Cl}^{-}$current with channel biophysical characteristics resembling those of $\mathrm{ClC}$ K2 and -2.

\section{MATERIALS AND METHODS}

\section{Tissue preparation and cell culture}

Two-week-old Sprague-Dawley rats were heavily anesthetized and decapitated. The inner ears were harvested rapidly and the spiral ligaments from two ears were dissected at $4^{\circ} \mathrm{C}$ under aseptic condition. The segment lying deep and inferior to the spiral prominence of the spiral ligament was collected and minced into small pieces using a corneal scissors. Some of the tissue pieces from each ear were collected and pooled for reverse transcriptase PCR (RT-PCR) analysis. The others were transferred to $35 \times 10$-mm petri dish (Corning Inc., Corning, NY, USA) for primary cell culture. The explants were kept in a $\mathrm{CO}_{2}$ incubator at $37^{\circ} \mathrm{C}$ and fed with media twice a week (Gratton et al. 1996; Liang et al. 2003). The culture media consists of $\alpha$-minimal essential medium supplemented with hydrocortisone $(36 \mathrm{ng} / \mathrm{ml}$ ), insulin $(5 \mu \mathrm{g} / \mathrm{ml})$, selenium ( $5 \mathrm{ng} / \mathrm{ml})$, transferrin $(5 \mu \mathrm{g} / \mathrm{ml})$, triiodothyronine $(4 \mathrm{pg} / \mathrm{ml}), 0.1 \%$ penicillin-streptomycin, and $10 \%$ fetal bovine serum, all purchased from Invitrogen Co. (Carlsbad, CA, USA). After reaching full confluence, the primary cultures were subcultured. The care and use of animals in this study was approved by the Medical University of South Carolina's Animal Review Committee under NIH grant no. DC00713.

\section{Immunocytochemistry}

Cultured fibrocytes were fixed with $10 \%$ formalin in phosphate-buffered saline (PBS) containing $0.5 \%$ zinc dichromate $(\mathrm{pH} 5.0)$ and permeabilized with $0.5 \%$ Triton X-100 before immunostaining. The primary antisera and dilutions were as follows: rabbit anti$\mathrm{Na}, \mathrm{K} / \mathrm{ATPase} 31 \mathrm{~B}$ at 1:500 (provided by Dr. G. J. Siegel, University of Michigan Medical School, Ann Arbor, MI, USA); mouse anti-Na,K,Cl-cotransporter T4 (provided by Dr. Cris Lytle, University of California, Riverside, CA, USA); rabbit anti-Ca/ATPase at 1:1,000 (from Dr. J. Lytton, Brigham and Women's Hospital, Boston, MA, USA); mouse antivimentin at 1:500 (BioGenex, San Ramon, CA, USA); mouse anticytokeratins AE1 and AE3 at 1:1,000 (Hybritech, San Diego, CA, USA); rabbit anticarbonic anhydrase isozyme II at 1:500 (Calbiochem, San Diego, CA, USA); and rabbit anticreatine kinase isozyme $\mathrm{BB}$ at 1:1,000 (Ventrex, Portland, ME, USA). After incubation with primary antiserum at $4^{\circ} \mathrm{C}$ overnight, the cells were rinsed in PBS before adding an appropriate fluorescein-isothiocyanate-conjugated secondary antibody diluted at 1:200 in PBS for $1 \mathrm{~h}$ at room temperature. The nuclei of cells were counterstained with Hoechst 3342 for 2 min and rinsed with 
PBS. Mounted slides were visualized and photographed using a Zeiss Axioplan fluorescence microscope.

\section{Transmission electron microscopy}

Fibrocytes grown to confluence in $25-\mathrm{mm}$ flasks (Corning) were rinsed with sterile $0.1 \mathrm{M}$ phosphate buffer (PB), fixed in situ for $30 \mathrm{~min}$ with $2.5 \%$ glutaraldehyde in $0.1 \mathrm{M} \mathrm{PB}(\mathrm{pH} 7.2)$ and postfixed for $1 \mathrm{~h}$ with $1 \% \mathrm{OsO}_{4}$ in $0.1 \mathrm{M} \mathrm{PB}$. They were dehydrated, infiltrated, and embedded in Embed 812 embedding resin (EMS, Port Washington, PA, USA). Thick sections were cut at $0.5-\mu \mathrm{m}$ thickness, stained with toluidine blue and examined with the light microscope. Blocks containing cells in an appropriate orientation were selected for thin sectioning. The 70-nm-thick thin sections were cut on a Reichert Ultracut E microtome (Leica, Germany) and contrasted with uranyl acetate and lead citrate for observation in a JEOL 1210 transmission electron microscope (JEOL USA, Inc., Peabody, MA, USA).

\section{Western blot analysis}

Confluent cells were washed with ice-cold PBS and lysed with $200 \mu \mathrm{l}$ Triton X-100 lysis buffer containing protease inhibitors (Roche Applied Science, Indianapolis, IN, USA). The extract was centrifuged at $14,000 \times g$ for $15 \mathrm{~min}$ at $4^{\circ} \mathrm{C}$. Supernatant protein concentration was determined by the bicinchoninic acid protein assay (Pierce Biotechnology, Inc., Rockford, IL, USA). A 30- $\mu$ g sample of protein was resolved on $10 \%$ sodium dodecyl (lauryl) sulfatepolyacrylamide gel, and then transferred to a polyvinylidene fluoride membrane. The membrane was blocked with $0.01 \%$ PBS Tween-20 containing 5\% nonfat dry milk at room temperature for $1 \mathrm{~h}$, washed, and incubated overnight at $4^{\circ} \mathrm{C}$ with a primary antiserum. The primary antisera used were against ClC-2 at 1:400 and ClC-K at 1:400 (Alomone Labs, Ltd., Israel). The blots were developed using enhanced chemiluminescence reagent (GE Healthcare Bio-Sciences Corp., Piscataway, NJ, USA). As a control, some blots were exposed to primary antiserum preincubated with blocking peptide at a concentration of $0.9 \mu \mathrm{g} / \mathrm{ml}$ for $30 \mathrm{~min}$ before use.

\section{RT-PCR analysis}

Cellular RNA was isolated by Trizol (Invitrogen Co.) from the cultured fibrocytes, skeletal muscle, lung, and three different regions of the cochlea: the stria vascularis, the organ of Corti, and the spiral ligament. One microgram of total RNA was reverse transcribed into cDNA using a RETROscript ${ }^{\circledR}$ Kit (Ambion, Inc., Austin, TX, USA). Sequences of PCR primers are provided in Table 1 . The specimens were preheated at $95^{\circ} \mathrm{C}$ for $3 \mathrm{~min}$ followed by 35 cycles at $95^{\circ} \mathrm{C}$ for $45 \mathrm{~s}$, $55^{\circ} \mathrm{C}$ for $1 \mathrm{~min}$, and $72^{\circ} \mathrm{C}$ for $1.5 \mathrm{~min}$. PCR products were separated on $1.5 \%$ agarose gels and products of

TABLE 1

Primers used in PCR experiments

\begin{tabular}{|c|c|c|c|}
\hline Primer & Oligonucleotide sequences $\left(5^{\prime}-3^{\prime}\right)$ & Product size (bp) & Reference \\
\hline \multirow[t]{2}{*}{$\mathrm{ClC}-1$} & F: TGTGGAACGCTCAGAACTGCAGTC & 656 & Kulka et al. 2002 \\
\hline & R: TCTAGTGCCAAGACACСТCTGAGC & & \\
\hline \multirow[t]{2}{*}{$\mathrm{ClC}-2$} & F: CAAGTTCСTCTCССТСTTTG & 499 & Enz et al. 1999 \\
\hline & R: GAACTGTCCAAAGCCAGGG & & \\
\hline \multirow[t]{2}{*}{$\mathrm{ClC}-3$} & F: CСТСТTTCCAAAGTATAGCAC & 552 & Enz et al. 1999 \\
\hline & R: TTACTGGCATTCATGTCATTTC & & \\
\hline \multirow[t]{2}{*}{$\mathrm{ClC}-4$} & F: GGTACATGGCTGAACTCTTC & 297 & Enz et al. 1999 \\
\hline & R: GAGTCATGTTGGGGTCATTG & & \\
\hline \multirow[t]{2}{*}{$\mathrm{ClC}-5$} & F: CTGTGCCACTGCTTCAAC & 556 & Auzanneau et al. 2003 \\
\hline & R: AGTGTTGAAGTGGTTCTC & & \\
\hline \multirow[t]{2}{*}{$\mathrm{ClC}-6$} & F: GCTGAGAGCCAGCGACATCA & 424 & Auzanneau et al. 2003 \\
\hline & R: AGCGGACGGAATCGCTCCT & & \\
\hline \multirow[t]{2}{*}{$\mathrm{ClC}-7$} & F: ATGAGCACGССТGTGACСТGССТG & 377 & Kulka et al. 2002 \\
\hline & R: CGAGGAAGAGATGCСТССТGTGGC & & \\
\hline \multirow[t]{2}{*}{ CIC-K1 } & F: CTCAAAGAGGCTGTGTGC & 391 & Ando and Takeuchi 2000 \\
\hline & R: TACGATGGCACCATCATG & & \\
\hline \multirow[t]{2}{*}{ CIC-K2 } & F: AAACCATCTTGACAGGTGTGA & 272 & Vandewalle et al. 1997 \\
\hline & R: GATTGGGGCGGCGAAGACC & & \\
\hline \multirow[t]{2}{*}{ CFTR } & F: CGCAGGTTCTCAGTGGACGATGCC & 607 & Huber et al. 1998 \\
\hline & R: CCTCAACCAGAAAAACCAGCACGCA & & \\
\hline \multirow[t]{2}{*}{ rig/S15 } & F: TTCCGCAAGTTCACCTACC & 361 & Inoue et al. 1987 \\
\hline & R: CGGGCCGGCCATGCTTTACG & & \\
\hline
\end{tabular}


predicted size were extracted using QIAquick gel extraction (Qiagen Inc., Valencia, CA, USA) and cloned into a TOPO TA Cloning vector (Invitrogen Co.). The sequences acquired from cloned plasmids were assessed using BLAST database at the National Center for Biotechnology Information. Negative controls were performed by omitting the reverse transcriptase in the $\mathrm{RT}$ reaction.

\section{In situ hybridization}

The detailed procedure for tissue processing was described previously ( $\mathrm{Qu}$ et al. 2006). In brief, the cochlease were fixed in $10 \%$ formalin containing $0.9 \% \mathrm{NaCl}$ and $0.5 \%$ zinc dichromate at $\mathrm{pH} 5.0$, decalcified in 0.12 M EDTA solution at $\mathrm{pH} 7.2$, and embedded in Paraplast Plus after dehydration. The tissue blocks were serially sectioned at $5 \mu \mathrm{m}$ in thickness and mounted on glass slides.

Digoxigenin (DIG)-labeled riboprobes for ClC-K2 were generated from PCR templates containing T7 and SP6 RNA polymerase promoters at both ends using a DIG RNA Labeling Kit (Roche Applied Science). The specific primer sequences were acquired from an earlier publication (Yoshikawa et al., 1999 ) with the sequences for EcoRI and BamHI sites substituted by sequences for T7 and SP6 RNA polymerase promoters, respectively.

The tissue sections were deparaffinized and rehydrated before incubation with either antisense or sense probes $(500 \mathrm{ng} / \mathrm{ml})$ for $16 \mathrm{~h}$ at $58^{\circ} \mathrm{C}$. The hybridization buffer consisted of $4 \times \mathrm{SSC}, 250 \mathrm{~g} / \mathrm{ml}$ yeast tRNA, $10 \mathrm{mM}$ DTT, $10 \%$ dextran sulfate, $2 \times$ Denhardt's solution, and $50 \%$ formamide. The posthybridization washes were done by incubation for $30 \mathrm{~min}$ in $2 \times \mathrm{SSC}$ at $25^{\circ} \mathrm{C}, 1 \mathrm{~h}$ in $2 \times \mathrm{SSC}$, and $1 \mathrm{~h}$ in $0.1 \times \mathrm{SSC}$ at $65^{\circ} \mathrm{C}$. The hybridized probes were detected by alkaline phosphatase-conjugated anti-DIG Fab fragments and NBT/BCIP substrate medium following instructions for the DIG Nucleic Acid Detection Kit (Roche Applied Science). The sections were then rinsed, dehydrated, and mounted in VectorShield (Vector, Burlingame, CA, USA).

\section{Whole-cell current recording}

The pipette tips were fire-polished with a microforge (WPI, Sarasota, FL, USA) to 2-4 M $\Omega$ resistance when filled with $140 \mathrm{mM} \mathrm{NaCl}$ solutions. The contents of pipette and bath solutions are shown in Table 2. The cultured fibrocytes were subjected to a short enzyme treatment $(0.05 \%$ trypsin-EDTA, $15 \mathrm{~min})$ and a gigaseal $(>5 \mathrm{G} \Omega)$ was formed between the cell membrane and the rim of the pipette opening by gentle suction. Further gentle suction was applied to break the patched cell membrane. Serial resistance and membrane capacitance were routinely measured and compensated to $\sim 70 \%$. Microcal Origin 5.0 and pClamp 8.0 software were used for data collection and analysis. The data were expressed as mean $\pm \mathrm{SE}$ $(N$, number of cells).

TABLE 2

\begin{tabular}{|c|c|c|c|c|c|c|c|}
\hline \multicolumn{8}{|c|}{ Whole-cell patch clamp solutions } \\
\hline & Pipette & Basic bath & $\begin{array}{l}\text { Bath }[\mathrm{Cl}] \\
50 \mathrm{mM}\end{array}$ & $\begin{array}{l}\text { Bath }\left[\mathrm{Ca}^{2+}\right] \\
\text { zero }\end{array}$ & $\begin{array}{l}\text { Bath } \\
\text { pH } 6.5\end{array}$ & $\begin{array}{l}\text { Bath } \\
\text { pH } 8.5\end{array}$ & Bath Nal \\
\hline $\begin{array}{c}\mathrm{TEA} / \mathrm{Cl} \\
(\mathrm{mM})\end{array}$ & 140 & 2 & 2 & 2 & 2 & 2 & 2 \\
\hline $\begin{array}{c}\text { EGTA } \\
(\mathrm{mM})\end{array}$ & 1 & 0 & 0 & 1 & 0 & 0 & 0 \\
\hline $\begin{array}{l}\mathrm{NaCl} \\
(\mathrm{mM})\end{array}$ & 0 & 150 & 46 & 150 & 150 & 150 & $\begin{array}{l}10 \mathrm{NaCl} \\
\text { and } 140 \mathrm{Nal}\end{array}$ \\
\hline $\begin{array}{l}\mathrm{CaCl}_{2} \\
(\mathrm{mM})\end{array}$ & 0.76 & 1 & 1 & 0 & 1 & 1 & 1 \\
\hline $\begin{array}{r}\mathrm{MgCl}_{2} \\
(\mathrm{mM})\end{array}$ & 1 & 1 & 1 & 0 & 1 & 1 & 1 \\
\hline $\begin{array}{l}\text { HEPES } \\
(\mathrm{mM})\end{array}$ & 10 & 10 & 10 & 10 & 10 & 10 & 10 \\
\hline $\begin{array}{l}\text { Glucose } \\
(\mathrm{mM})\end{array}$ & 0 & 10 & 10 & 10 & 10 & 10 & 10 \\
\hline $\begin{array}{l}\mathrm{pH} \\
\text { (with } \mathrm{NaOH} \text { ) }\end{array}$ & 7.4 & 7.4 & 7.4 & 7.4 & 6.5 & 8.5 & 7.4 \\
\hline $\begin{array}{l}\text { Osmolarity } \\
(\mathrm{osm} / \mathrm{l})\end{array}$ & 270 & 300 & 300 adjusted with Mannitol & 300 & 300 & 300 & 300 \\
\hline
\end{tabular}

EGTA = ethylene glycol bis(2-aminoethyl ether)- $N, N, N^{\prime}, N^{\prime}$-tetraacetic acid 

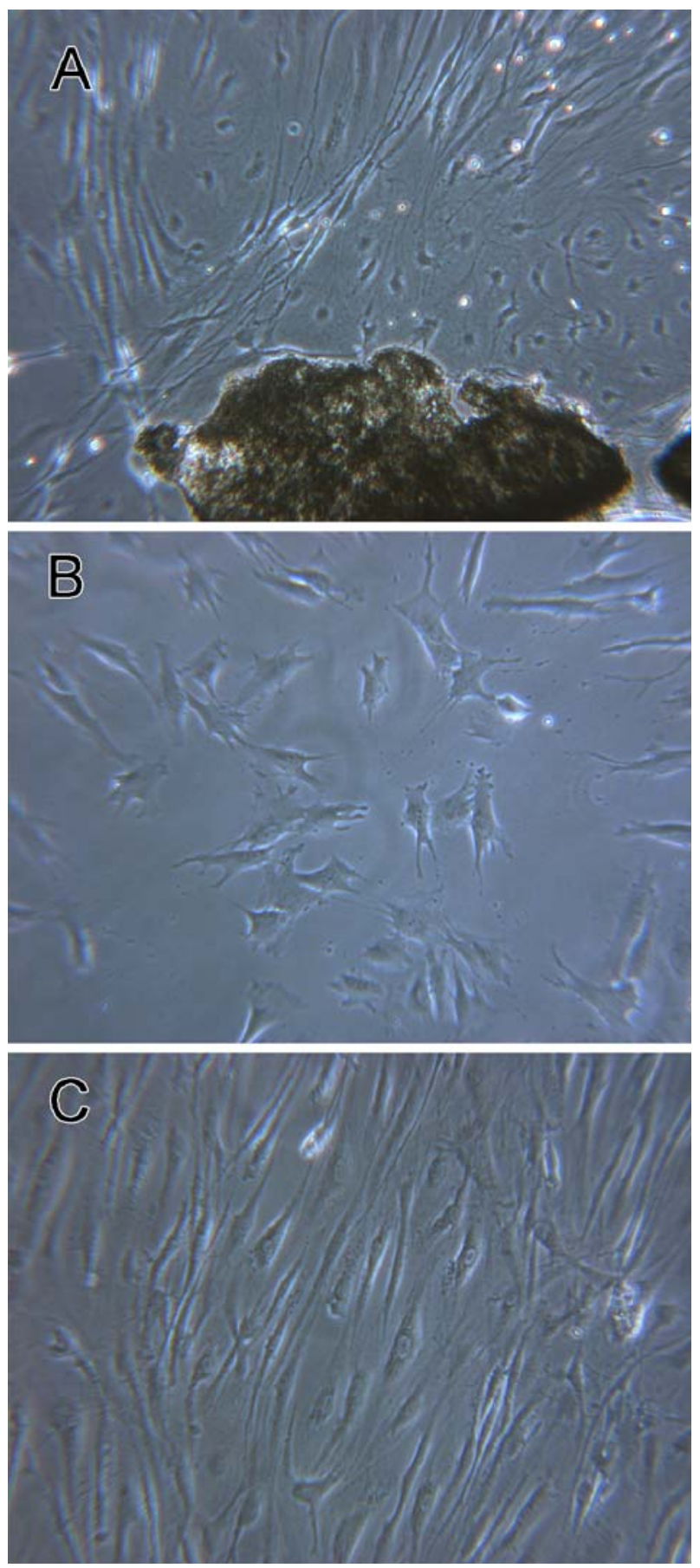

FIG. 1. Phase contrast images of cultured spiral ligament fibrocytes. A Fibrocytes grow out of an explant of spiral ligament in the primary culture. B Fibrocytes in the first passage of secondary culture. C Confluent fibrocytes in the secondary culture. $\times 60$ for subpanel $\mathbf{A}, \times 100$ for subpanels $\mathbf{B}$ and $\mathbf{C}$.

\section{RESULTS}

Characterization of cultured cells

Sparse stellate-shaped cells appeared at the edge of the explant between 3-7 days in the primary culture.
Spindle-shaped cells with slender processes gradually occupied the area surrounding the explant (Fig. 1A). Cells in the secondary culture exhibited a stellate morphology with irregular cell processes before confluence (Fig. 1B), but acquired the spindleshaped morphology of typical fibrocytes upon reaching confluence (Fig. 1C).

Ultrastructural observations of confluent secondary cultures revealed several layers of cells with narrow overlapping processes (Fig. 2A). Each cell contained a single elongated nucleus. Scattered mitochondria and rough endoplasmic reticulum made up the majority of the organelles (Fig. 2B). Profiles of small round vesicles, presumably secretary in nature, were frequently seen underlying the plasma membrane (Fig. 2C). The relatively narrow extracellular spaces between the cells contained accumulations of fibrous and amorphous materials. The cell surfaces were generally smooth and lacked microvilli and plasmalemmal evaginations. Although the cell membranes were frequently in close contact, gap junctions were not observed between cell bodies and/or their processes.

The secondary cultures were further characterized using a panel of antibodies directed against protein markers specific for the different subpopulations of spiral ligament fibrocytes (Table 3). Positive staining for vimentin, but not cytokeratins (Fig. 3A, B), suggested the embryonic mesodermal rather than ectodermal or endodermal origin of the cells. The cultured cells showed moderate to strong immunostaining for carbonic anhydrase II, creatine kinase BB, $\mathrm{Na}, \mathrm{K}, \mathrm{Cl}$-cotransporter, and $\mathrm{Na}, \mathrm{K} / \mathrm{ATPase}$, but failed to react with antiserum to $\mathrm{Ca} / \mathrm{ATPase}$ (Fig. $3 \mathrm{C}-\mathrm{G}$ ). No immunoreactivity was observed in cultured cells when nonimmune serum was used in place of primary antiserum (Fig. $3 \mathrm{H}$ ). This immunostaining profile for the cultured cells was consistent with that for type IV fibrocytes in vivo.

\section{Expression of ClC-K2 mRNA in the cochlea}

Both ClC-K1 and -K2 were identified in the spiral ligament using Western blot and RT-PCR procedures (Qu et al. 2006). However, because the antiserum used in the previous study did not discriminate between the $\mathrm{K} 1$ and $\mathrm{K} 2$ variants, in situ hybridization was employed here to define the cell type-specific distribution of ClC-K2 in the cochlea. Strong staining was present in types II, IV, and V spiral ligament fibrocytes, limbal fibrocytes, ganglion neurons, and osteoclasts in the otic capsule in sections hybridized with ClC-K2 antisense probes (Fig. 4). No detectable hybridization signal was present in types I or III spiral ligament fibrocytes, the organ of Corti, or the stria 

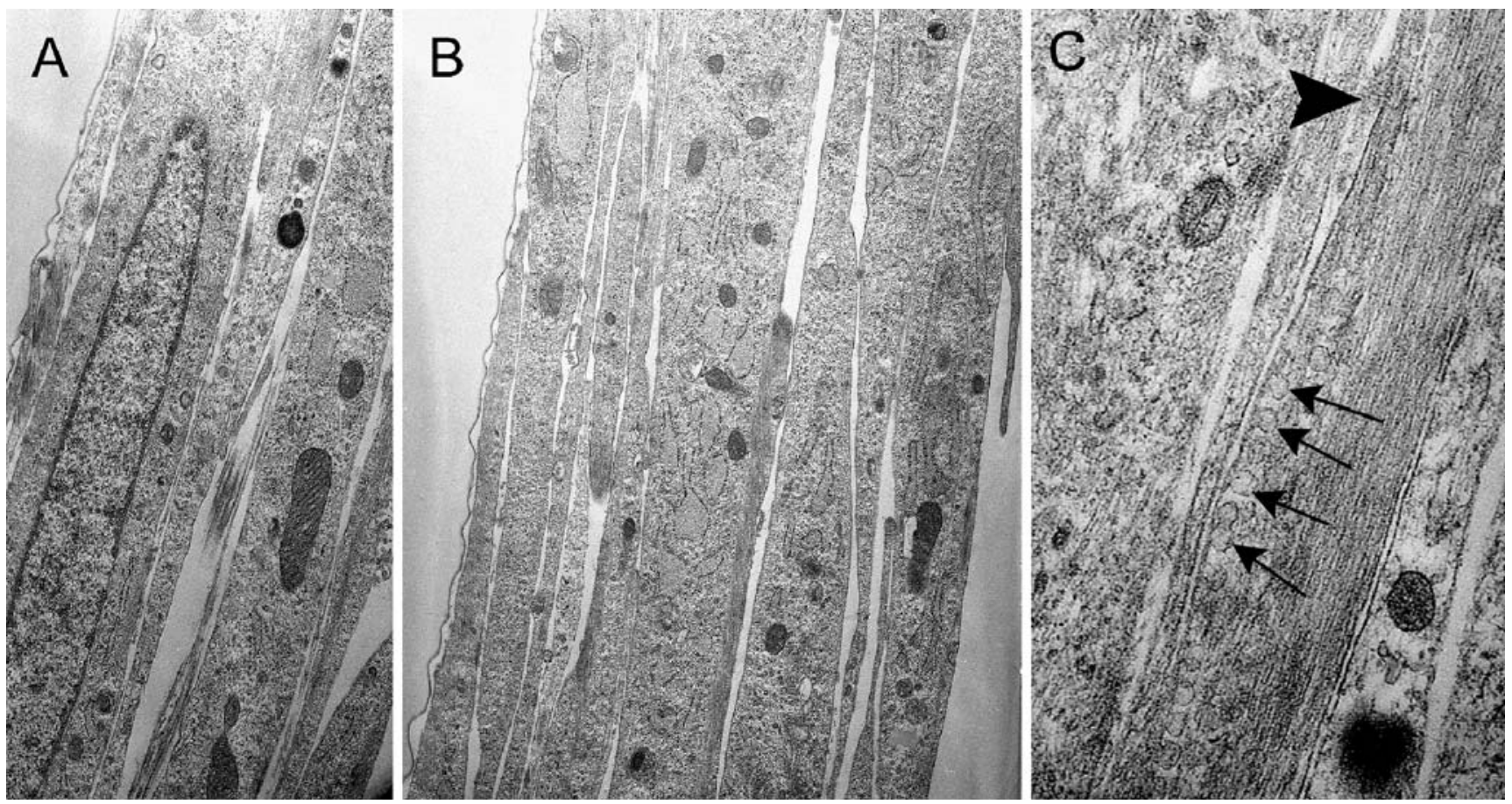

FIG. 2. Ultrastructure of confluent cells in secondary culture. A, B Sections cut perpendicular to the surface of the culture dish reveal several layers of spindle-shaped cell with elongated nuclei. The slender processes are closely apposed to each other with little intercellular separation and contain abundant dilated rough endoplasmic reticulum and different-sized mitochondria. C Numerous small round vesicles (arrows) are present beneath the plasma membrane in one process near an extracellular accumulation of amorphous material (arrowhead). $\times 5,000$ for subpanel A, ×6,500 for subpanel B, and $\times 10,000$ for subpanel $\mathbf{C}$.

vascularis. There was no staining when a sense DIG probe was used for hybridization (data not shown).

Expression of ClC-K2, but not ClC-K1, in the cultured fibrocytes

The expression of known $\mathrm{ClC}$ and the CFTR channels was investigated in the cultured cells and the spiral ligament by RT-PCR analysis. Total RNA isolated from the cultured cells and the region of spiral ligament from which they were obtained were analyzed with primers specific for ClCs and CFTR as listed in Table 1. Messenger RNAs for ClC-2, -3, -4, -5, $-6,-7$, and $-\mathrm{K} 2$ were detected in secondary cell cultures and tissue preparations, but mRNA of ClC$\mathrm{K} 1$ was present only in spiral ligament tissues (Fig. 5A, B). In contrast, mRNA for ClC-1 and CFTR was not detected either in the cultured cells or tissues. To

TABLE 3

\begin{tabular}{|c|c|c|c|c|c|c|}
\hline \multicolumn{7}{|c|}{ Immunocytochemical profile of spiral ligament fibrocytes } \\
\hline \multirow[b]{3}{*}{ Antigen } & \multicolumn{5}{|c|}{ In vivo ${ }^{a}$} & \multirow{2}{*}{$\frac{\text { In vitro }}{\text { Cultured spiral ligament fibrocyte type }}$} \\
\hline & \multicolumn{5}{|c|}{ Spiral ligament fibrocyte types } & \\
\hline & 1 & II & III & IV & V & IV \\
\hline Vimentin & + & - & + & + & - & + \\
\hline Cytokeratins & - & - & - & - & - & - \\
\hline Carbonic anhydrase II & + & - & + & + & + & + \\
\hline Creatine kinase BB & + & - & + & + & + & + \\
\hline Ca/ATPase & + & - & - & - & - & - \\
\hline $\mathrm{Na}, \mathrm{K}, \mathrm{Cl}$-cotransporter & - & + & - & + & + & + \\
\hline $\mathrm{Na}, \mathrm{K} / \mathrm{ATP}$ ase & - & + & $-1+$ & + & $-1+$ & + \\
\hline
\end{tabular}

\footnotetext{
${ }^{\mathrm{a} G r a t t o n}$ et al. 1996
} 

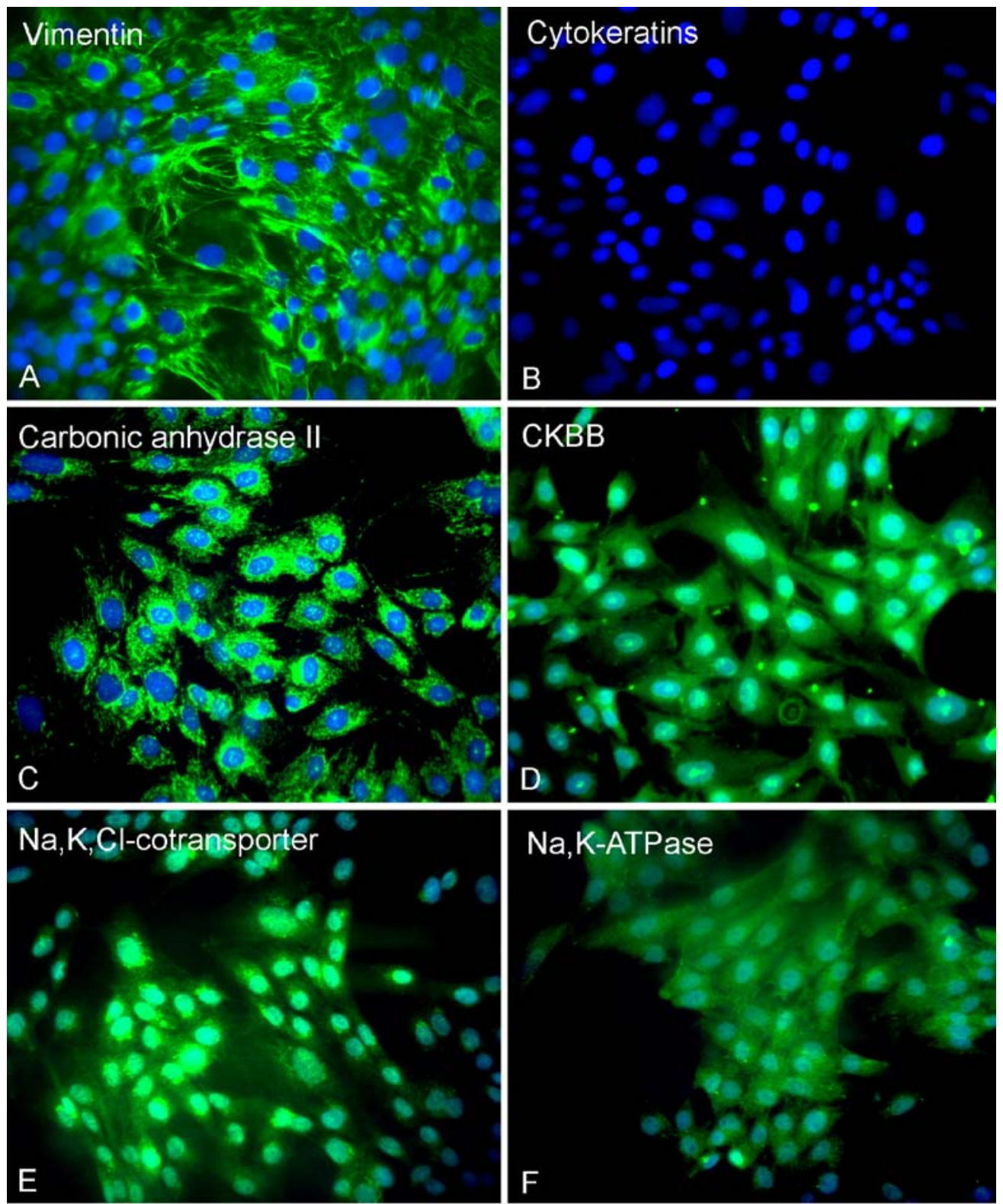

Na,K-ATPase

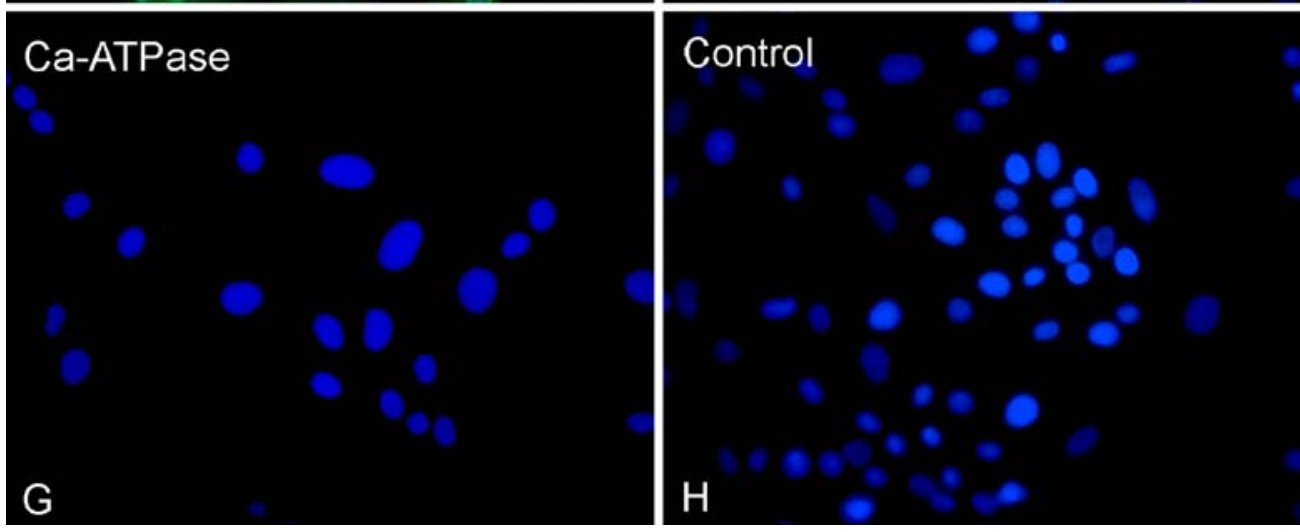

FIG. 3. Immunocytochemical staining of secondary cultures. A Vimentin, B cytokeratins, C carbonic anhydrase II, D creatine kinase BB (CKBB), E Na,K,Cl-cotransporter, $\mathbf{F ~ N a , K / A T P a s e , ~} \mathbf{G ~ C a / A T P a s e , ~ a n d ~} \mathbf{H}$ negative control. $\times 125$. 


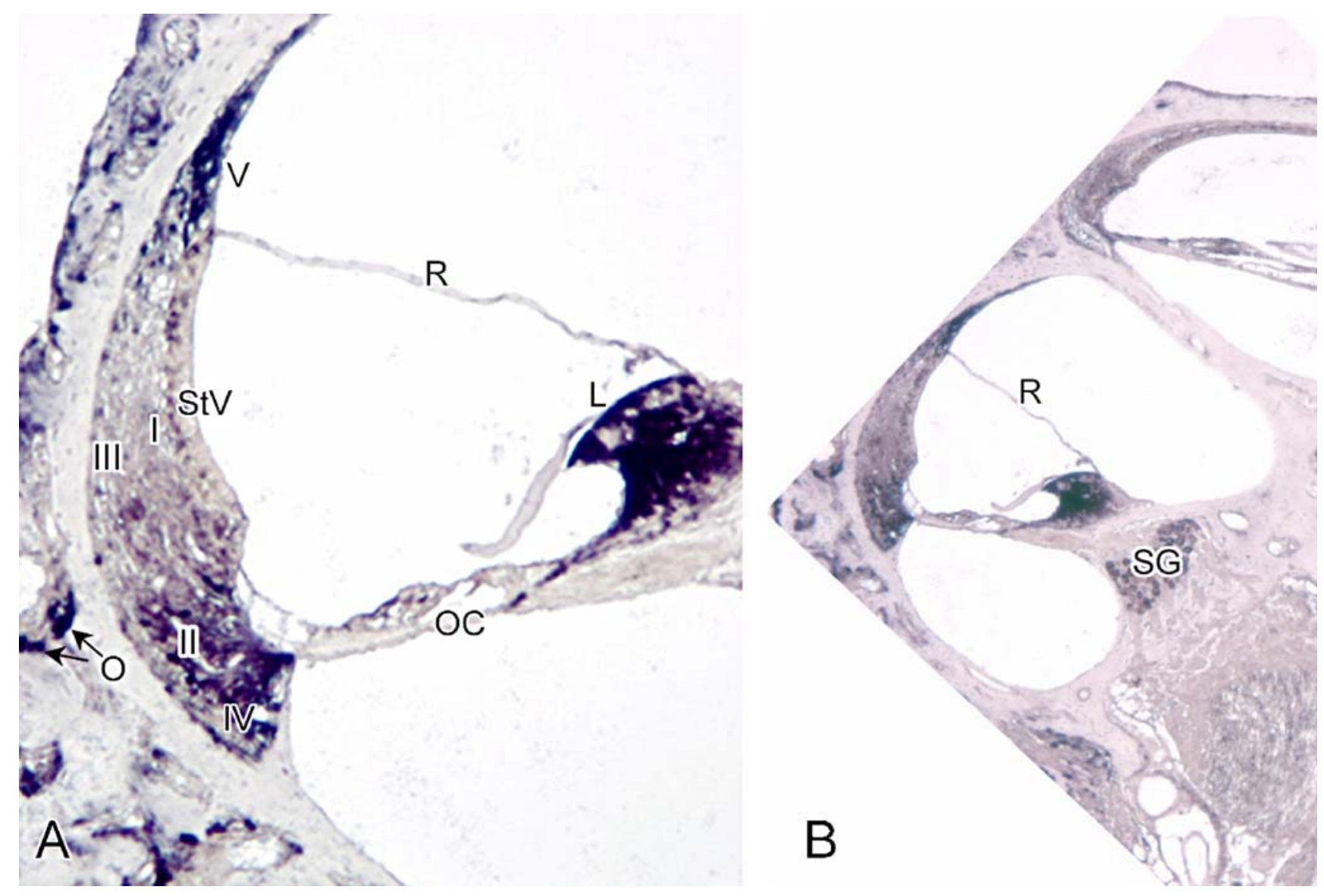

FIG. 4. In situ hybridization of DIG-labeled rat CIC-K2 antisense probe to an adult rat cochlea. A Intense hybridization signals were present in limbal, types II, IV, and V fibrocytes, and osteoclasts (O) in the otic capsule. No detectable signal was observed in type I or III spiral ligament fibrocytes, the organ of Corti (OC) or the stria vascularis (StV). B Strong hybridization signals were seen in spiral ganglion neurons (SG). $\times 125$ for subpanel $\mathbf{A}$ and $\times 40$ for subpanel $B$. $R=$ Reissner's membrane.

ensure that the lack of amplification for skeletal muscle specific ClC-1 (Steinmeyer et al. 1991) and CFTR in cultured cells was not owing to the PCR conditions, we confirmed the presence of the corresponding transcripts in positive control tissues known to express these channels (Fig. 5C). Control experiments in which no reverse transcriptase was added to the reactions to test for genomic DNA contamination of RNA samples were uniformly negative (data not shown).

ClC-3 to -7 are thought to be expressed only in membranes of intracellular organelles (Jentsch et al. 2005) and thus would not be expected to contribute to whole-cell $\mathrm{Cl}^{-}$currents. However, $\mathrm{ClC}-2$ and $-\mathrm{K} 2$ are located in the plasma membrane and their expression in the cultured cells was further analyzed by Western blot (Fig. 6). Preincubation of each antiserum with its matched peptide eliminated the staining of the blots (data not shown). Although the antibody against $\mathrm{ClC}-\mathrm{K}$ is unable to discriminate between $\mathrm{K} 1$ and $\mathrm{K} 2$ variants, the positive band is most likely attributable to ClC-K2 because ClC-K1 mRNA was not detected in the cultured cells.

\section{Recording of ClC-K2-like and ClC-2-like} whole-cell $\mathrm{Cl}^{-}$currents in cultured cells

In the whole-cell patch clamp studies, tetraethylammonium (TEA) was used as the major cation in the pipette solution to block simultaneous $\mathrm{K}^{+}$activity and thus to study the $\mathrm{Cl}^{-}$currents in isolation. To avoid activation of swelling-activated chloride channels, the osmolarity of the pipette solution was kept $10 \%$ below that of bath solution. The currents were recorded at least $1 \mathrm{~min}$ after the establishment of whole-cell configuration.

Using a voltage protocol that stepped from a holding potential of $0 \mathrm{mV}$ through voltages ranging 


\section{A Cultured fibrocytes}

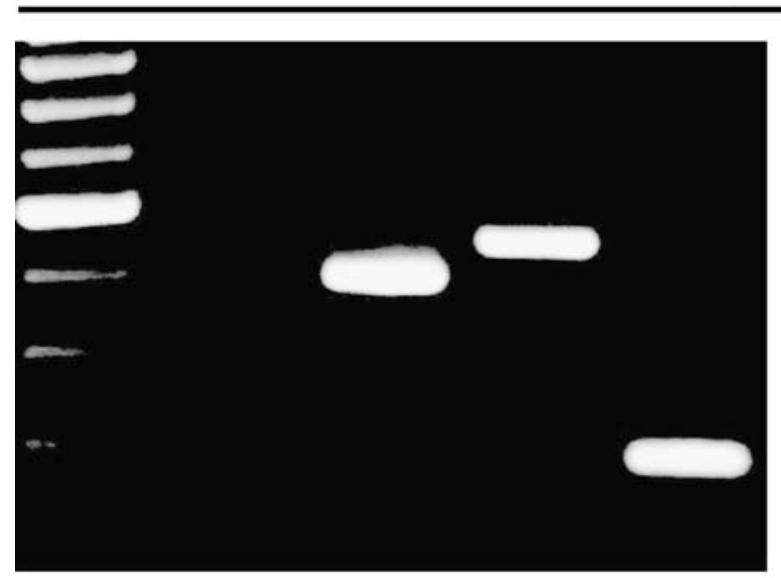

m ClC-1 ClC-2 $\quad \mathrm{ClC}-3 \quad \mathrm{ClC}-4$

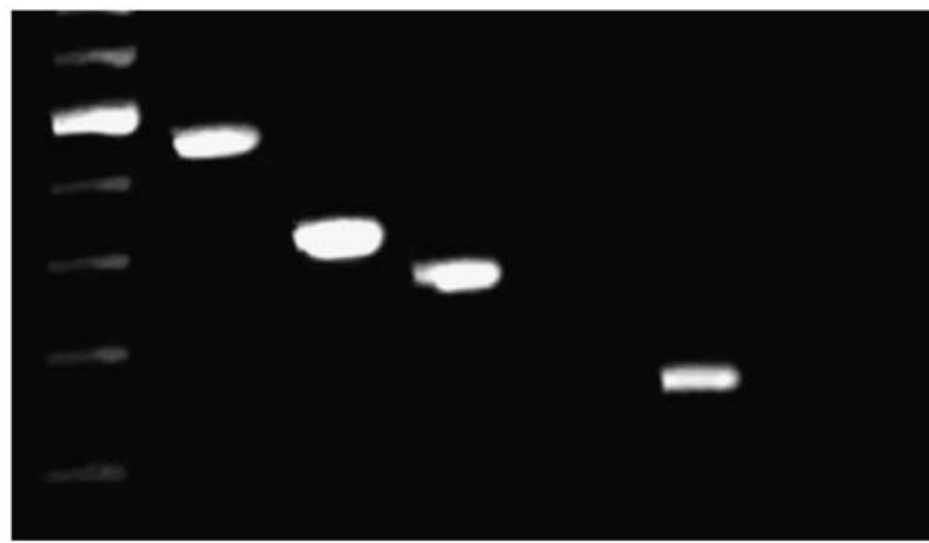

m ClC-5 ClC-6 ClC-7 CIC CIC CFTR $-\mathrm{K} 1 \quad-\mathrm{K} 2$

\section{B Spiral ligament}

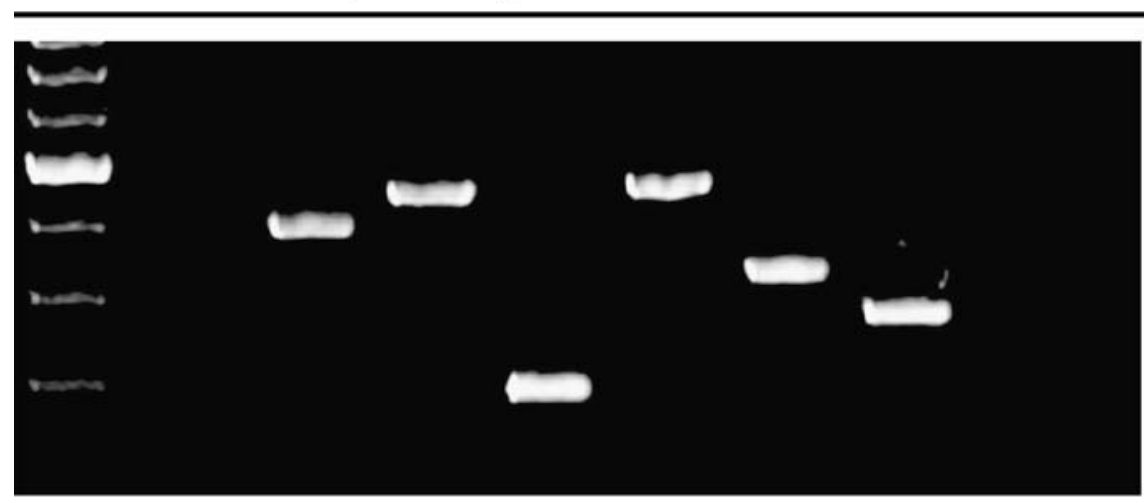

m $\mathrm{ClC} \quad \mathrm{ClC} \quad \mathrm{ClC} \quad \mathrm{ClC} \quad \mathrm{ClC} \quad \mathrm{ClC} \quad \mathrm{ClC}$ CFTR

$\begin{array}{lllllll}-1 & -2 & -3 & -4 & -5 & -6 & -7\end{array}$

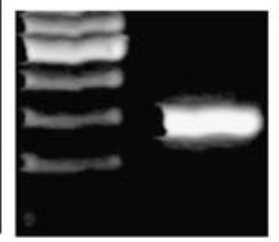

$\mathrm{CIC}$ $-\mathrm{K} 1$

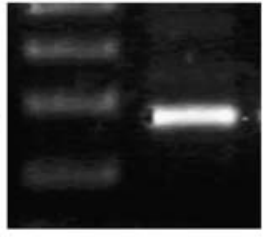

$\mathrm{CIC}$ $-\mathrm{K} 2$

\section{Muscle Lung}

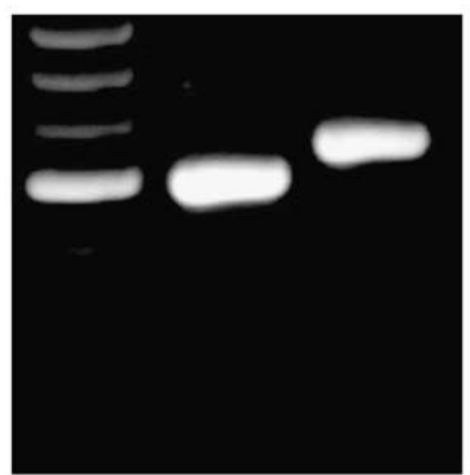

m CIC-1 CFTR

FIG. 5. RT-PCR amplification of the CIC channel family and CFTR. A Cultured type IV fibrocytes. B Freshly isolated spiral ligament. C Skeletal muscle and lung samples used as positive control for CIC-1 and CFTR, respectively. Lane m, molecular weight marker. 


\section{$\mathrm{ClC}-\mathrm{K} \quad \mathrm{ClC}-2$}
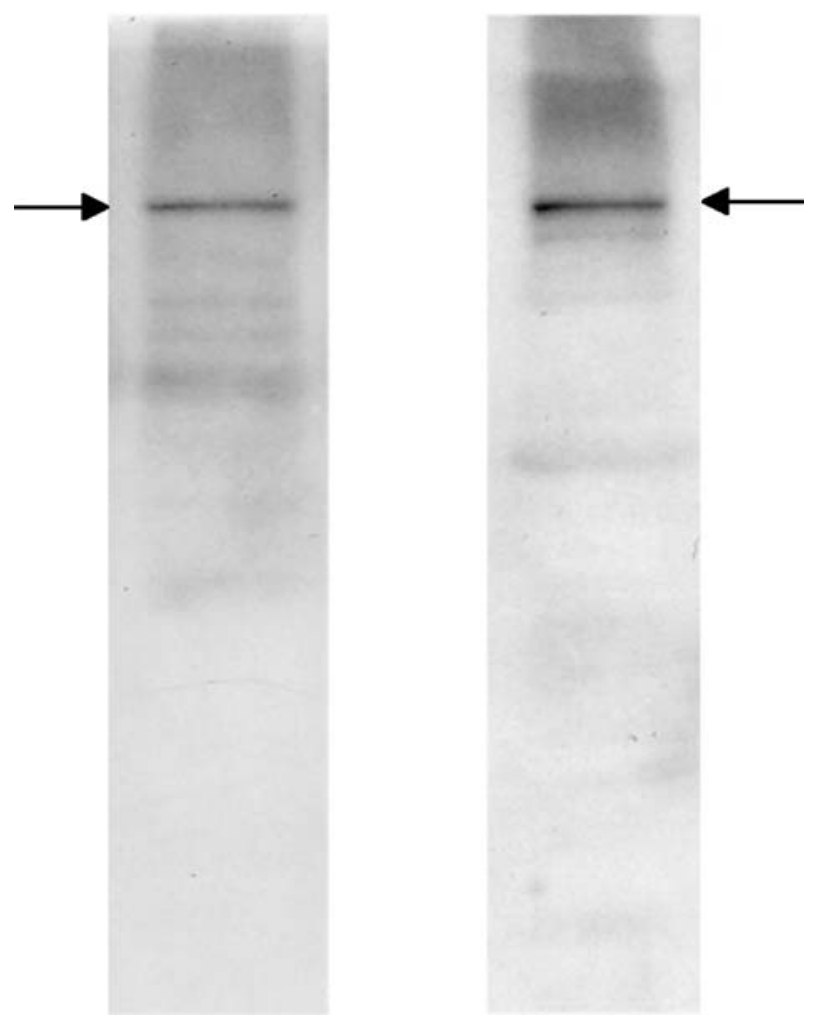

FIG. 6. Western blot analysis of proteins from cultured fibrocytes. Anti-ClC-K and anti-ClC-2 recognize a band at $\sim 100 \mathrm{kDa}$. The position of the reactive bands is indicated by arrows.

from -100 to $+100 \mathrm{mV}$ in $20 \mathrm{mV}$ steps, small currents were observed that increased in amplitude in response to depolarizing voltage steps $(n=15$, Fig. 7A, B). The current/voltage (I/V) relationship (Fig. 7C) showed a weak outward rectification. To determine the anion permeability of the currents, we performed anion substitution experiments in which $\mathrm{Cl}^{-}$ $(150 \mathrm{mM})$ in the bath solution was partially replaced with $\mathrm{I}^{-}(140 \mathrm{mM})$. The changes in the reversal potential and current amplitude were evaluated. The shift of the reversal potential in a positive direction indicated that $\mathrm{I}^{-}$is less permeable than $\mathrm{Cl}^{-}$ (Fig. 7D), which is an important property of $\mathrm{ClC}$ currents (Chen 2005). We also found that the wholecell currents were regulated by extracellular $\mathrm{pH}$ changes and $\mathrm{Cl}^{-}$and $\mathrm{Ca}^{2+}$ concentrations, but not cyclic AMP. The current amplitude increased markedly with a bath $\mathrm{pH}$ change from 7.4 to 6.5 and decreased sharply when extracellular $\mathrm{pH}$ was alkalinized from 7.4 to 8.5 (Fig. 8A). Changing the $\left[\mathrm{Cl}^{-}\right]$in the bath solution from 150 to $50 \mathrm{mM}$ caused a marked decrease in current, which was reversible (Fig. 8B). A change in the extracellular $\left[\mathrm{Ca}^{2+}\right]$ from $1 \mathrm{mM}$ to nominally 0 led to a marked reduction of currents over the measured voltage range (Fig. 8C).
However, the introduction of extracellular cyclic AMP in a cocktail containing $10 \mu \mathrm{M}$ Forskolin and $100 \mu \mathrm{M}$ IMBX had no significant effect on channel activity (Fig. 8D). These electrophysiological characteristics closely resemble those of ClC-Kb channels (human homolog of ClC-K2) when expressed in Xenopus oocytes with the exception of $\mathrm{pH}$, which has an opposite effect (Estevez et al. 2001; Waldegger et al. 2002).

When we changed the protocol to hyperpolarizing voltage steps ranging from -140 to $+60 \mathrm{mV}$, hyperpolarization-activated $\mathrm{Cl}^{-}$currents occasionally could be recorded ( $n=2$, Fig. 9). The characteristics of these inward rectifying currents, including the timedependence and activation by lowering extracellular $\mathrm{pH}$, were typical of ClC-2 channel currents recorded in mammalian cells or when heterologously expressed in Xenopus oocytes (Thiemann et al. 1992; Jordt and Jentsch 1997; Schwiebert et al. 1998).

\section{DISCUSSION}

Taking advantage of the well-established distribution of spiral ligament fibrocyte subtypes, we were able to use microdissection techniques to isolate and establish primary and secondary cultures of type IV fibrocytes. The identity of the cultured cells was verified immunocytochemically with protein markers specific for various spiral ligament cell types. The cultured type IV fibrocytes appeared to maintain their in vivo immunostaining profile as do cultured type I fibrocytes (Gratton et al. 1996; Liang et al. 2003). The type IV fibrocytes appeared to have a higher cytoplasmic to nuclear area ratio and more abundant mitochondria than was seen in type I secondary cultures and also contained numerous small round vesicles beneath their plasma membrane. These vesicles and the extensive network of dilated rough endoplasmic reticulum are indicative of active protein synthesis and secretion by these cells. The amorphous material observed in the intercellular spaces in the cultures shared similar ultrastructural features with that seen in type I fibrocyte cultures and may represent collagen and fibronectin as in other fibroblast cell cultures (Goldberg and Green 1964; Hedman et al. 1978; Gratton et al. 1996).

Also similar to type I fibrocytes in culture, the cultured type IV fibrocytes failed to form gap junction connections with one another even at confluence (Liang et al. 2003). These results suggest that a particular microenvironment may be required to facilitate the formation of the extensive gap junctions that occur between spiral ligament fibrocytes in vivo. This supposition is supported by data 
A
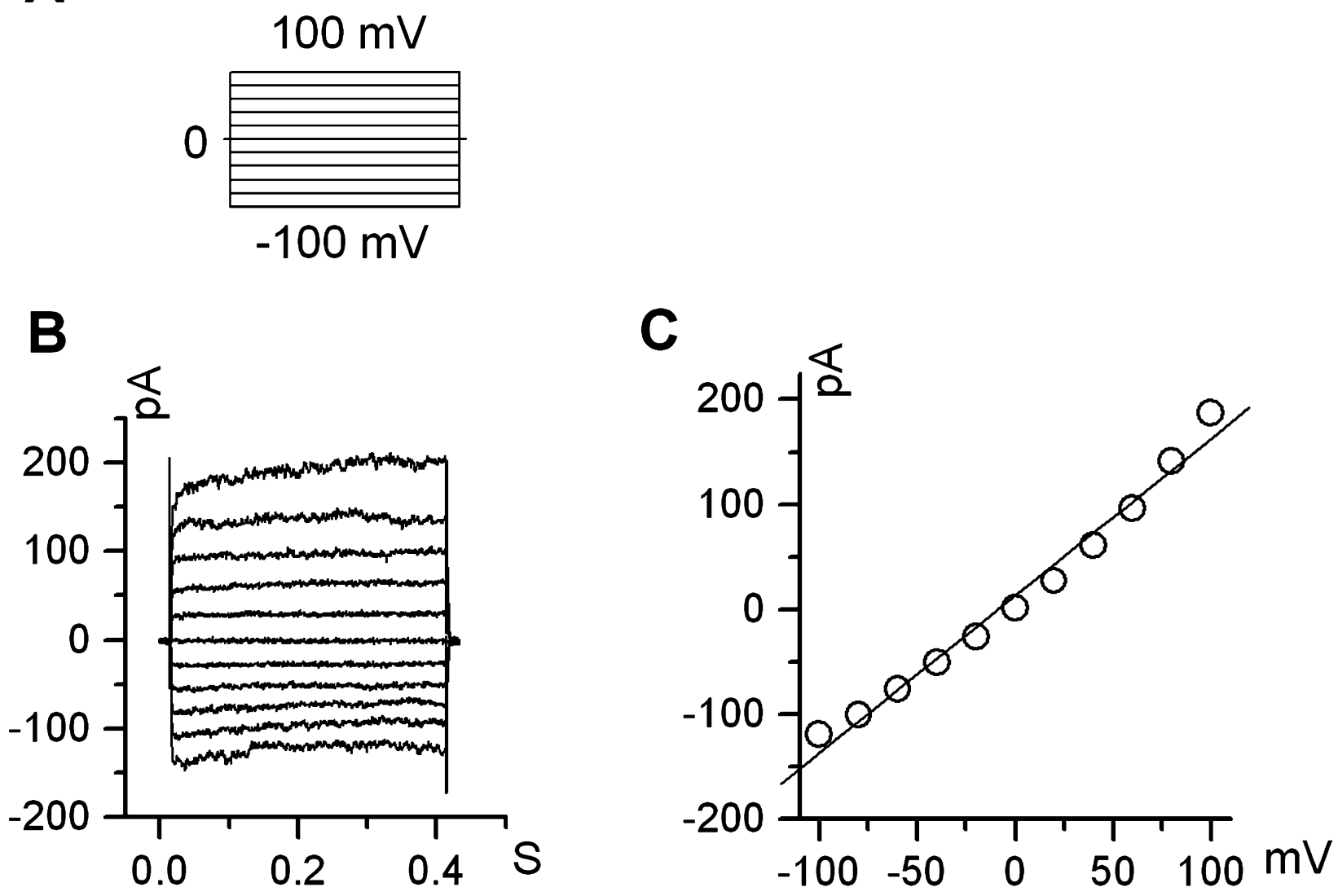

D

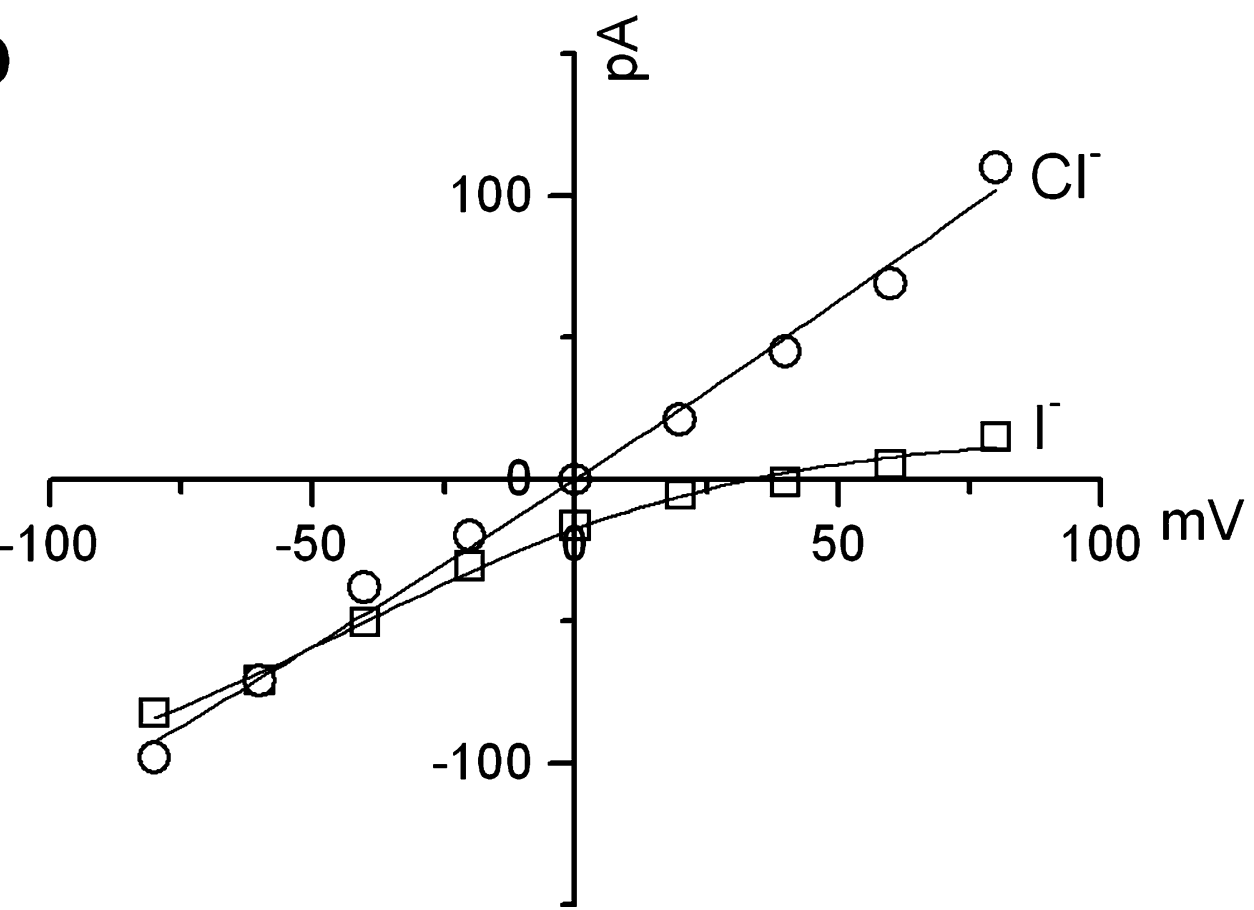

FIG. 7. Outward whole-cell $\mathrm{Cl}^{-}$current in cultured fibrocytes. A The pulse voltage protocol of a series of $400 \mathrm{mS}$ pulses from a holding potential of $0 \mathrm{mV}$ through a range of -100 to $+100 \mathrm{mV}$ in $20 \mathrm{mV}$ steps. B A representative current trace recording with $140 \mathrm{mM} \mathrm{Cl}^{-}$in the pipette and $150 \mathrm{mM} \mathrm{Cl}^{-}$in the bath. C Current-voltage relations at the end of voltage pulses derived from subpanel B demonstrate weak outward rectification. D Anion selectivity comparison between $\mathrm{Cl}^{-}$and $\mathrm{I}^{-}$. 
A

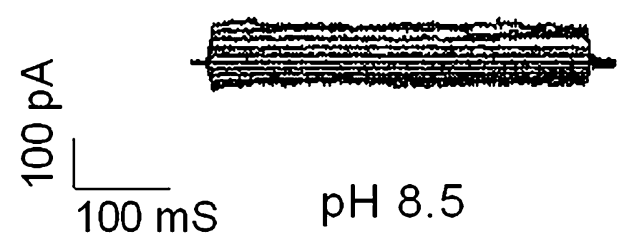

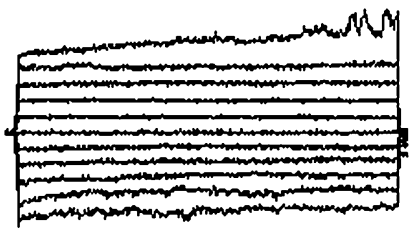

$\mathrm{pH} 7.4$

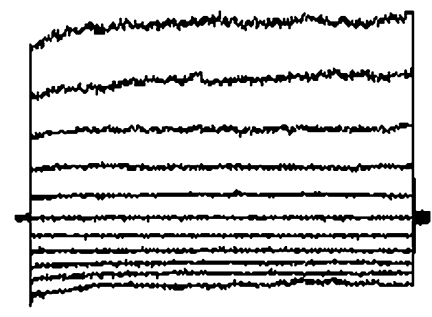

$\mathrm{pH} 6.5$

B

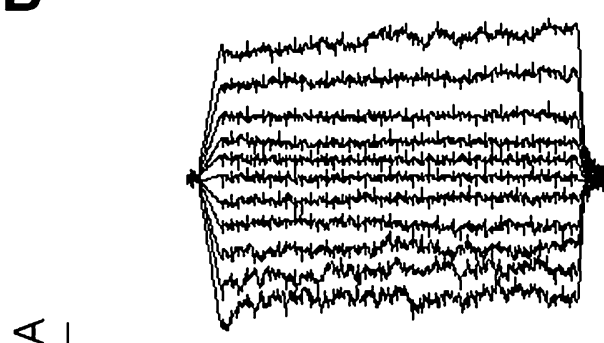

$\frac{\pi}{8}$

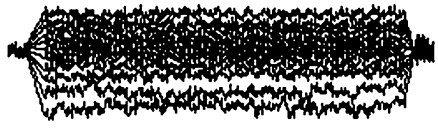

$[\mathrm{Cl}]=50 \mathrm{mM}$

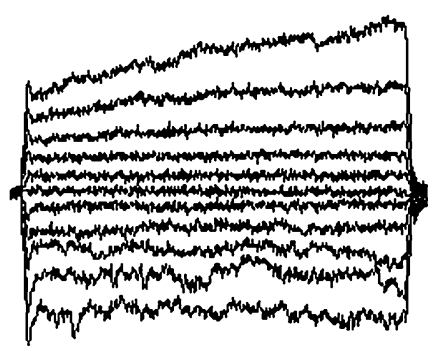

$[\mathrm{Cl}]=150 \mathrm{mM}$

$100 \mathrm{~ms}$

C
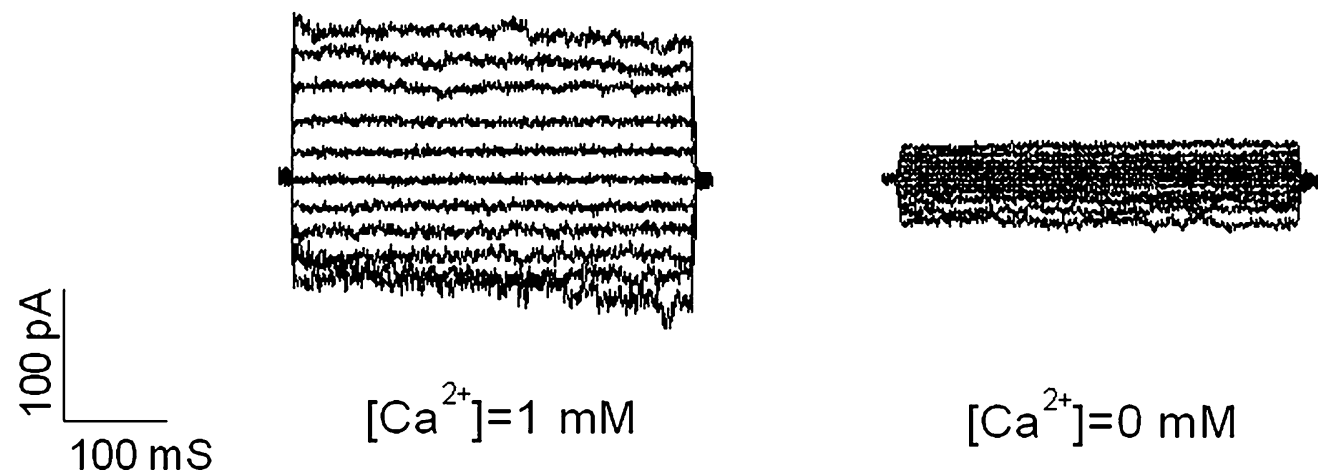

$\mathbf{D}$
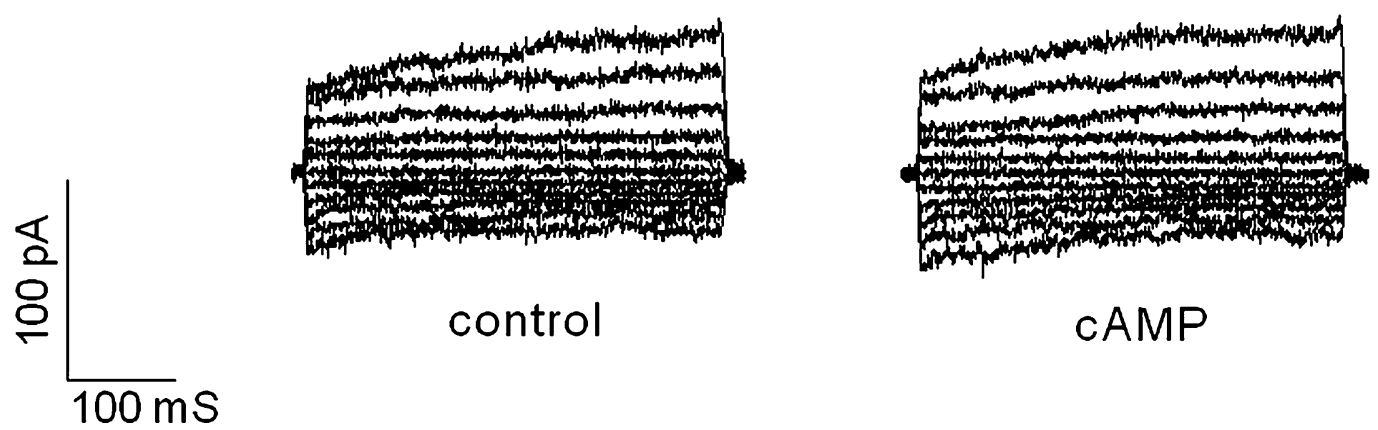

FIG. 8. Effects of extracellular $\mathrm{pH}, \mathrm{Cl}^{-}$and $\mathrm{Ca}^{2+}$ concentration, and cyclic AMP on outward whole-cell $\mathrm{Cl}^{-}$currents in cultured type IV fibrocytes. Currents were reduced by extracellular alkalization $(\mathbf{A})$ and decreased extracellular $\mathrm{Cl}^{-}(\mathbf{B})$, or $\mathrm{Ca}^{2+}(\mathbf{C})$ concentrations. The currents were not regulated by extracellular cAMP (D). 
A
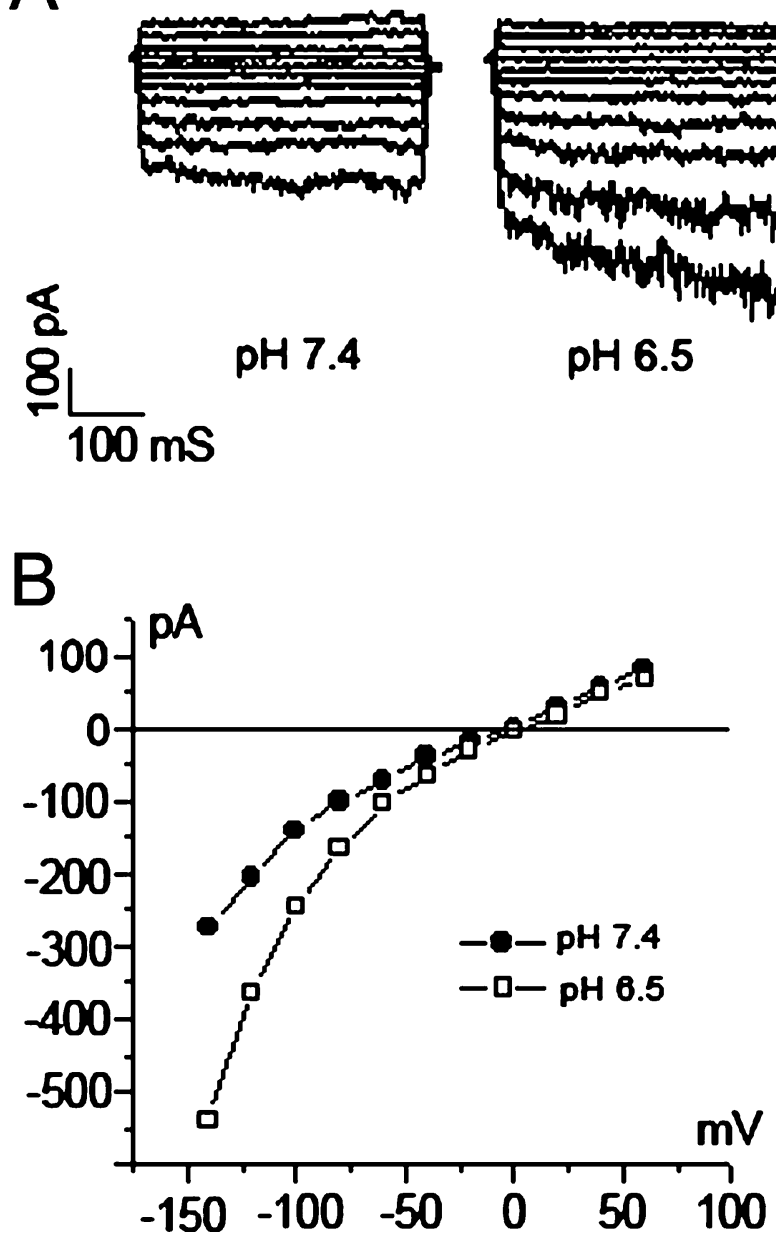

FIG. 9. Inward ClC-2-like whole-cell chloride currents in cultured fibrocytes. The pulse-voltage protocol is a series of 400-mS pulses from a holding potential of $0 \mathrm{mV}$ through a range of -140 to $+60 \mathrm{mV}$ in $20 \mathrm{mV}$ steps. A Representative traces of inward $\mathrm{Cl}^{-}$currents at $\mathrm{pH}$ 7.4 and 6.5. B I/ $\mathrm{V}$ relation plot derived from $\mathrm{A}$ at the end of voltage pulses.

showing that two different cultured hepatoma cell lines (7777 and H4IIE-C3) are deficient in connexin $(\mathrm{Cx})$ expression and gap junction-mediated intercellular communication, but when transplanted into muscle to form tumors these cell lines expressed Cx32 mRNA at a level of $15-70 \%$ of that found in normal liver tissues (Neveu et al. 1994). Another hepatoma cell line (9618A) expressed Cx43 mRNA and protein in vitro but switched to express Cx32 mRNA in vivo. These data indicate that Cx expression, at least in hepatoma cells, is dependent on environmental influences and suggests the possibility of inducing gap junction formation between type IV fibrocytes by altering the composition of the medium or other culture conditions.

Although a few members of the $\mathrm{ClC}$ family have previously been identified in the inner ear (Oshima et al. 1997; Kawasaki et al. 1999; Ando and Takeuchi
2000; Kawasaki et al. 2000; Sage and Marcus 2001), this is the first report documenting a complete gene expression profile for the entire $\mathrm{ClC}$ family in the spiral ligament. The RT-PCR results showed that mRNAs for ClC-2 to -7 are present in the spiral ligament and in type IV fibrocytes isolated and cultured from this tissue region. However, the skeletal muscle-specific ClC-1 was not detected in either preparation, consistent with expectations from studies in other tissues (Steinmeyer et al. 1991; Jentsch et al. 1995; Olsen et al. 2003; Davies et al. 2004). The broad tissue distribution patterns of ClC-2 to -7 indicate their essential roles in basic cellular functions, including volume regulation and acidification of intracellular vesicles. In contrast, $\mathrm{ClC}-\mathrm{K} 1$ and $\mathrm{K} 2$ are expressed specifically in the kidney where they function in transepithelial $\mathrm{Cl}^{-}$transport and in the inner ear where they appear to mediate the exit of $\mathrm{Cl}^{-}$from cells after its active uptake by the $\mathrm{K}, \mathrm{Cl}-$ cotransporter and/or the $\mathrm{Na}, \mathrm{K}, \mathrm{Cl}-$ cotransporter $(\mathrm{Qu}$ et al. 2006). Our earlier work also suggested that the $\mathrm{K} 1$ and $\mathrm{K} 2$ variants are coexpressed in many inner ear cell types and may have the capacity to compensate for one another functionally. This compensatory relationship was proposed because normal hearing is preserved with the loss-of-function of either variant, as demonstrated in ClC-K1 knockout mouse and Bartter's syndrome type III (Simon et al. 1997; Matsumura et al. 1998). On the other hand, the loss of both ClC-Ks or their common $\beta$-subunit results in deafness (Estevez et al. 2001; Schlingmann et al. 2004).

Message for $\mathrm{ClC}-\mathrm{K} 1$ and -K2 was present in regions of freshly isolated spiral ligament tissues that were seeded for the primary cultures. However, mRNA for ClC-K1 was not detectable in the cultured type IV fibrocytes, suggesting either that it is not normally present in this fibrocyte subtype or that its expression is down regulated under cell culture conditions. The latter prospect is not unreasonable because, for instance, a differential transcriptional effect underlies the loss of tissue specificity in primary cultures of mouse hepatocytes with decline of liver-specific mRNA (Clayton and Darnel 1983). Also, freshly isolated skeletal muscle from newborn rats expressed both $\alpha 1$ and $\alpha 2$ subunits of the $\mathrm{Na}, \mathrm{K} / \mathrm{ATPase}$, whereas skeletal muscle in culture expresses only the $\alpha 1$ subunit isoform (Sharabani-Yosef et al. 1999).

Both the ClC-K2 and -2 variants were detected in cultured type IV fibrocytes using RT-PCR and Western blot procedures. Because we wished to investigate the electrophysiological feature of whole-cell chloride currents in the cultured fibrocytes under nonstimulatory conditions, the recordings were performed using a weak hypoosmotic intracellular solution $(90 \%$ of osmolarity of the extracellular solution) to minimize swell- 
ing-activated chloride currents. The $\mathrm{ClC}-2$ and $-\mathrm{K} 2$ currents were measured in different cells using different pulse voltage protocols. The general electrophysiological characteristics of ClC-2-mediated whole-cell currents include swelling activation, inward rectification, and activation by lowering extracellular $\mathrm{pH}$. Observations of currents with such features were rare, being seen only twice. These findings suggest that the major role of ClC-2 in type IV fibrocytes may be in regulating cell volume (Gründer et al. 1992; Obermuller et al. 1998). In all other cases, the recorded currents had characteristics closely resembling those for ClC-K2, including outward rectification regulated by extracellular $\mathrm{Cl}^{-}$and $\mathrm{Ca}^{2+}$ concentration and the relative anion permeability of $\mathrm{Cl}^{-}>\mathrm{I}^{-}$(Waldegger and Jentsch 2000). However, we cannot exclude the possibility that a minor portion of the current could be carried by $\mathrm{ClC}-2$, as suggested by the opposite regulatory effects of extracellular $\mathrm{pH}$. Although ClC-2 and $-\mathrm{K} 2$ are likely coexpressed in all of the cultured cells, the experimental conditions used here made it difficult to record ClC-2 currents. In addition, the expression of ClC-2 can vary with the state of the cell cycle (Furukawa et al. 2001). A relatively low and variable level of expression of $\mathrm{ClC}-2$ is consistent with the other data here, which strongly suggest that ClC-K2 is the dominant chloride channel in the plasma membrane of cultured type IV fibrocytes.

\section{ACKNOWLEDGMENTS}

This work was supported by grant no. R01 DC00713 from the National Institute on Deafness and Other Communication Disorders and grant no. C06 RR014516 from the Extramural Research Facilities Program of the National Center for Research Resources, National Institutes of Health.

\section{REFERENCES}

ANDo M, TAKEUCHI S. mRNA encoding ClC-K1, a kidney $\mathrm{Cl}^{-}$-channel is expressed in marginal cells of the stria vascularis of rat cochlea: its possible contribution to $\mathrm{Cl}^{-}$currents. Neurosci. Lett. 284:171-174, 2000.

Auzanneau C, Thoreau V, Kitzis A, Bece F. A Novel voltage-dependent chloride current activated by extracellular acidic $\mathrm{pH}$ in cultured rat Sertoli cells. J. Biol. Chem. 278:19230-19236, 2003.

Boettger T, Hubner CA, Maier H, Rust MB, Beck FX, Jentsch TJ. Deafness and renal tubular acidosis in mice lacking the K-Cl cotransporter Kcc4. Nature 416:874-878, 2002.

Chen TY. Structure and function of clc channels. Annu. Rev. Physiol. 67:809-839, 2005.

Clayton DF, Darnell JE Jr. Changes in liver-specific compared to common gene transcription during primary culture of mouse hepatocytes. Mol. Cell Biol. 3:1552-1561, 1983.
Crouch JJ, Sakaguchi N, Lytle C, Schulte BA. Immunohistochemical localization of the Na-K-Cl co-transporter (NKCC1) in the gerbil inner ear. J. Histochem. Cytochem. 45:773-778, 1997.

Davies N, Akhtar S, Turner HC, Candia OA, To CH, Guggenheim JA. Chloride channel gene expression in the rabbit cornea. Mol. Vis. 10:1028-1037, 2004.

Enz R, Ross BJ, Cutting GR. Expression of the voltage-gated chloride channel ClC-2 in rod bipolar cells of the rat retina. J. Neurosci. 19:9841-9847, 1999.

Estevez R, JENTSCH TJ. CLC chloride channels: correlating structure with function. Curr. Opin. Struct. Biol. 12:531-539, 2002.

Estevez R, Boettger T, Stein V, Birkenhager R, Otto E, Hildebrandt F, JENTSCH TJ. Barttin is a $\mathrm{Cl}^{-}$channel beta-subunit crucial for renal $\mathrm{Cl}^{-}$reabsorption and inner ear $\mathrm{K}^{+}$secretion. Nature 414:558561, 2001.

Furukawa T, Zheng Y, Ogura T, Katayama Y, Inagaki N. Modulation of Cl- channel by cell cycle clock. Kidney Int. 60:405, 2001.

Goldberg B, Green H. An analysis of collagen secretion by established mouse fibroblast lines. J. Cell Biol. 22:227-258, 1964.

Gratton MA, Schulte BA, Hazen-Martin DJ. Characterization and development of an inner ear type I fibrocyte cell culture. Hear. Res. 99:71-78, 1996.

Gründer S, Thiemann A, Pusch M, Jentsch TJ. Regions involved in the opening of $\mathrm{ClC}-2$ chloride channel by voltage and volume. Nature 360:759-762, 1992.

Hedman K, Vaheri A, Wartiovaara J. External fibronectin of cultured human fibroblasts is predominantly a matrix protein. J. Cell Biol. 76:748-760, 1978.

Huber S, Braun G, Burger-Kentischer A, Reinhart B, Luckow B, Horster M. CFTR mRNA and its truncated splice variant (TRNCFTR) are differentially expressed during collecting duct ontogeny. FEBS Lett. 423:362-366, 1998.

Inoue C, Shiga K, Takasawa S, Kitagawa M, Үамamoto H, Окamoto H. Evolutionary conservation of the insulinoma gene rig and its possible function. Proc. Natl. Acad. Sci. USA 84:6659-6662, 1987.

Jentsch TJ, Pusch M, Rehfeldt A, Steinmeyer K. The ClC family of voltage-gated chloride channels: structure and function. Ann. N. Y. Acad. Sci. 707:285-293, 1993.

Jentsch TJ, Gunther W, Pusch M, Schwappach B. Properties of voltage-gated chloride channels of the $\mathrm{ClC}$ gene family. J. Physiol. 482:19S-25S, 1995.

Jentsch TJ, Neagoe I, Scheel O. ClC chloride channels and transporters. Curr. Opin. Neurobiol. 15:319-325, 2005.

Jordt SE, Jentsch TJ. Molecular dissection of gating in the ClC-2 chloride channel. EMBO J. 16:1582-1592, 1997.

Kawasaki E, Hattori N, Miyamoto E, Yamashita T, Inagaki C. Singlecell RT-PCR demonstrates expression of voltage-dependent chloride channels (ClC-1, ClC-2 and ClC-3) in outer hair cells of rat cochlea. Brain Res. 838:166-170, 1999.

Kawasaki E, Hattori N, Miyamoto E, Yamashita T, Inagaki C. mRNA expression of kidney-specific ClC-K1 chloride channel in single-cell reverse transcription-polymerase chain reaction analysis of outer hair cells of rat cochlea. Neurosci. Lett. 290: 76-78, 2000.

Kulka M, Schwingshackl A, Befus AD. Mast cells express chloride channels of the ClC family. Inflamm. Res. 51:451-456, 2002.

Kunzelmann K. The cystic fibrosis transmembrane conductance regulator and its function in epithelial transport. Rev. Physiol. Biochem. Pharmacol. 137:1-70, 1999.

Liang F, Niedzielski A, Schulte BA, Spicer SS, Hazen-Martin DJ, SHen Z. A voltage- and $\mathrm{Ca}^{2+}$-dependent big conductance $\mathrm{K}$ channel in cochlear spiral ligament fibrocytes. Pflugers Arch. 445:683-692, 2003.

Matsumura Y, Uchida S, Kondo Y, Miyazaki H, Ko SB, Hayama A, Morimoto T, Liu W, Arisawa M, Sasaki S, Marumo F. Overt 
nephrogenic diabetes insipidus in mice lacking the CLC-K1 chloride channel. Nat. Genet. 21:95-98, 1998.

Neveu MJ, Sattler CA, Sattler GL, Hully JR, Hertzberg El, Paul DL, Nicholson BJ, Рitot HC. Differences in the expression of connexin genes in rat hepatomas in vivo and in vitro. Mol. Carcinog. 11:145-154, 1994.

Obermuller N, Gretz N, Kriz W, Reilly RF, Witzgall R. The swelling-activated chloride channel ClC-2, the chloride channel ClC-3, and ClC-5, a chloride channel mutated in kidney stone disease, are expressed in distinct subpopulations of renal epithelial cells. J. Clin. Invest. 101:635-642, 1998.

Olsen ML, Schade S, Lyons SA, Amaral MD, Sontheimer H. Expression of voltage-gated chloride channels in human glioma cells. J. Neurosci. 23:5572-5582, 2003.

Oshima T, IKEDA K, Furukawa M, TAKasaKa T. Expression of voltagedependent chloride channels in the rat cochlea. Hear. Res. 103:63-68, 1997.

Qu C, Liang F, Hu W, Shen Z, Spicer SS, Schulte BA. Expression of ClC-K chloride channels in the rat cochlea. Hear. Res. 213:7987, 2006.

Riordan JR, Rommens JM, Kerem B, Alon N, Rozmahel R, Grzelczak Z, Zielenski J, Lok S, Plavsic N, Chou JL, Drumm ML, Iannuzzi MC, Collins FS, Tsur LC. Identification of the cystic fibrosis gene: cloning and characterization of complementary DNA. Science 245:1066-1073, 1989.

SAGE CL, Marcus DC. Immunolocalization of ClC-K chloride channel in strial marginal cells and vestibular dark cells. Hear. Res. 160:1-9, 2001.

Schlingmann KP, Konrad M, Jeck N, Waldegger P, Reinalter SC, Holder M, Seyberth HW, Waldegger S. Salt wasting and deafness resulting from mutations in two chloride channels. N. Engl. J. Med. 350:1314-1319, 2004.

Schwiebert EM, Cid-Soto LP, Stafford D, Carter M, Blaisdell CJ, Zeituin PL, Guggino WB, Cutting GR. Analysis of ClC-2 channels as an alternative pathway for chloride conduction in cystic fibrosis airway cells. Proc. Natl. Acad. Sci. USA 95:3879-3884, 1998.

Sharabani-Yosef O, Bak A, Langzam L, Lui Z, Nir U, Braiman L, SweAdner KJ, SAMpson SR. Rat skeletal muscle in culture expresses the alphal but not the alpha2 protein subunit isoform of the $\mathrm{Na}^{+} / \mathrm{K}^{+}$pump. J. Cell Physiol. 180:236-244, 1999.

Shen Z, Liang F, Hazen-Martin DJ, Schulte BA. BK channels mediate the voltage-dependent outward current in type I spiral ligament fibrocytes. Hear. Res. 187:35-43, 2004.

Simon DB, Bindra RS, Mansfield TA, Nelson-Williams C, Mendonca E, Stone R, Schurman S, Nayir A, Alpay H, Bakkaloglu A, RodriguezSoriano J, Morales JM, Sanjad SA, Taylor CM, Pilz D, Brem A, Trachtman H, Griswold W, Richard GA, John E, Lifton RP. Mutations in the chloride channel gene, CLCNKB, cause Bartter's syndrome type III. Nat. Genet. 17:171-178, 1997.

Spicer SS, Schulte BA. Differentiation of inner ear fibrocytes according to their ion transport related activity. Hear. Res. 56:53-64, 1991.

Sitcer SS, Schulte BA. The fine structure of spiral ligament cells relates to ion return to the stria and varies with place-frequency. Hear. Res. 100:80-100, 1996.

Sitcer SS, Schulte BA. Evidence for a medial $\mathrm{K}^{+}$recycling pathway from inner hair cells. Hear. Res. 118:1-12, 1998.

Sitcer SS, Duncan I, Schulte BA. Immunolocalization of the chloride channel ClC-K in inner ear and other histological sites. In: Association for Research in Otolaryngology Abstracts of the 26th annual midwinter research meeting, 110, 2003.

Steinmeyer K, Klocke R, Ortland C, Gronemeier M, Jockusch H, GRUNDER S, JENTSCH TJ. Inactivation of muscle chloride channel by transposon insertion in myotonic mice. Nature 354:304-308, 1991.

Suko T, Ichimiya I, Yoshida K, Suzuki M, Mogi G. Classification and culture of spiral ligament fibrocytes from mice. Hear. Res. 140:137-144, 2000.

Thiemann A, Grunder S, Pusch M, Jentsch TJ. A chloride channel widely expressed in epithelial and non-epithelial cells. Nature 356:57-60, 1992.

Vandewalle A, Cluzeaud F, Bens M, Kieferle S, Steinmeyer K, Jentsch TJ. Localization and induction by dehydration of $\mathrm{ClC}-\mathrm{K}$ chloride channels in the rat kidney. Am. J. Physiol. 272:678-688, 1997.

Yoshikawa M, Uchida S, Yamuchi A, Miyai A, Tanaka Y, Sasaki S, MARUmo F. Localization of rat CLC-K2 chloride channel mRNA in the kidney. Am. J. Physiol. 276(4 Pt 2): F552-F558, 1999.

WALDEGGER S, JeNTSCH TJ. Functional and structural analysis of ClC$\mathrm{K}$ chloride channels involved in renal disease. J. Biol. Chem. 275:24527-24533, 2000.

Waldegger S, Jeck N, Barth P, Peters M, Vitzthum H, Wolf K, Kurtz A, KonRAD M, SEYBerth HW. Barttin increases surface expression and changes current properties of $\mathrm{ClC}-\mathrm{K}$ channels. Pflugers Arch. 444:411-418, 2002. 